\title{
IMPLEMENTASI STRATEGI KOMUNIKASI PEMASARAN PADA MAJALAH AULEEA SEBAGAI MAJALAH DAKWAH
}

\author{
Eka Anjani \\ STID Al-Hadid, Surabaya \\ khaylillakamelia@gmail.com
}

\begin{abstract}
Abstrak: Majalah Auleea adalah salah satu media cetak berplatform dakwah khusus Muslimah. Majalah ini bisa dikatakan survive dalam menghadapi kompetisi berbagai media majalah selainnya. Setiap bulan jumlah oplah Majalah Auleea mencapai 5000an, dapat dikategorikan sebuah oplah yang relatif sukses. Melalui tulisan ini digambarkan bagaimana penerapan strategi pemasaran Majalah Auleea dengan menggunakan komunikasi pemasaran. Teori yang digunakan adalah teori strategi komunikasi pemasaran milik Kotler dan Fandi Ciptono. Studi dilaksanakan dengan pendekatan deskriptif kualitatif, yang datanya didapatkan dari jajaran direksi, redaksi, dan tim pemasaran Majalah Auleea, sedangkan metode pengumpulan data menggunakan teknik wawancara dan dokumen terkait. Harapannya studi ini bisa memberikan manfaat dan pelajaran bagi media cetak Islam (Muslimah) yang lainnya, utamanya yang baru atau belum berkembang. Hasil studi menunjukkan bahwa tujuan komunikasi majalah Auleea ada tiga, yakni tujuan kognisi, afeksi, dan konasi. Untuk tahap kognisi majalah Auleea lebih banyak menggunakan saluran iklan baik melalui media cetak dan media radio sedangkan untuk tahap afeksi dan konasi melalui pemasaran langsung, promo, media sosial dan event. Sedangkan apabila ada target pasar yang tidak sependapat dengan isi majalah maka digunakan komunikasi public relation.

Kata kunci: strategi komunikasi pemasaran, Majalah Auleea, media cetak Muslimah
\end{abstract}

\begin{abstract}
Auleea is one of printing media/magazines which has da'wah platform for female Moslems. This magazine can survive in dealing with a competition with other magazines. This magazine has a circulation of 5,000 and can be categorized as a relatively successful circulation. This paper illustrates on how the implementation of its marketing strategy which is used marketing communication. The theory of marketing communication strategy used is Kotler and Fandi Ciptono's. The study is conducted by qualitative descriptive approach. Its data are obtained from the management, editorial staffs, and marketing team of Auleea's magazine. The method of collecting the data is from interview and supporting documents. It is hoped that the study can provide benefits and lessons for other Islamic printing media (female Moslems), especially the new and not-developed ones. The study indicates that there are 3 aims of communication of Auleea, namely cognitive, affective and conation. For cognitive phase, Auleea uses more advertisement channel, both through printing media, and radio. For affective and conation phase, Auleea uses direct marketing, promo, social media and events. When there are market targets who do not agree with the content of magazine, Auleea uses communication of public relation.
\end{abstract}

Keywords: marketing communication strategy, Auleea Magazine, printing media for female moslems 


\section{Pendahuluan}

Pada era modern dan seiring tingginya konsumsi informasi, mendorong berdirinya perusahaan media massa. Ketika semakin banyak perusahaan media yang didirikan, akan semakin sengit persaingan antar perusahaan untuk memperebutkan pasar dan pengiklan. Medan persaingan terjadi mulai dari pembuatan produk, strategi pemasaran hingga komunikasi pemasaran. ${ }^{1}$ Strategi komunikasi pemasaran merupakan akhir dari setiap proses dan berhubungan langsung dengan konsumen. oleh karena itu, agar strategi komunikasi pemasaran tepat maka perusahaan akan membagi pasar ke dalam berbagai segmen pasar yang potensial, dapat diukur, dapat dijangkau dan spesifik, seperti segmen pasar yang berdasarkan gender, lokasi, pekerjaan, pendapatan, usia, pendidikan, dan sebagainya. ${ }^{2}$

Melihat berbagai segmen tersebut, segmen wanita merupakan segmen potensial, hal ini dapat dilihat banyaknya majalah-majalah perempuan yang beredar masyarakat baik media cetak atau media online seperti Majalah Cosmopolitan, Hai, Kawanku, Kartini, Femina, Gadis, Annida, Ummi, Sakinah dan sebagainya. Majalah-majalah tersebut sampai saat ini ada yang

1 Rhenald Kasali, Membidik Pasar Indonesia: Segmentasi, Targetting, dan Positioning (Jakarta: Gramedia Pustaka, 1998), 67.

2 Ibid., 67.

3 Annida, Annida Goes to Andalusia, https://www.annida-online.com/annida-goes-toandalusia/

4 Restu diantina Putri, Krisis Femina Group: Gaji wartawan bisa dicicil dan bisnis singset majalah https://tirto.id/krisis-femina-group-gaji-wartawandicicil-bisnis-singset-majalah-czsf, 2 November 2017 diproduksi dalam media cetak dan ada yang sudah menghentikan media cetak kemudian beralih pada media online. Seperti Annida, majalah ini sempat tidak menerbitkan cetak pada tahun 2009 kemudian beralih ke media online, kemudian tahun 2013 mulai cetak lagi akan tetapi hanya terbit setiap tiga bulan sekali, ${ }^{3}$ majalah Kawanku dan Hai sudah beralih ke media online dan tidak lagi menerbitkan versi media cetak. ${ }^{4}$

Hadirnya majalah Auleea sebagai pemain baru dalam bisnis majalah akan menambah semakin maraknya persaingan majalah di Indonesia. Majalah yang di produksi oleh PT. Aula Media NU ini adalah majalah dakwah dengan segmentasi keluarga muslimah, ${ }^{5}$ majalah ini memiliki orientasi untuk mengenalkan nilai-nilai NU dan sekaligus sebagai wadah suara wanita Nahdlatul Ulama. ${ }^{6}$ Majalah yang baru berdiri pada tahun 2015 ini, memiliki oplah kurang lebih 4.000 eksemplar. ${ }^{7}$ Selain itu majalah ini lebih marketable, indikasinya adalah dari iklan yang dimuat meliputi White Coffee, Semen Gresik, dan Honda Beat. Majalah khusus perempuan muslimah pertama yang berhaluan ahlussunnah wal jamaah ini telah tersebar di beberapa provinsi di Indonesia seperti Jakarta dan Jawa Tengah. $^{8}$ Majalah Auleea yang ingin

\footnotetext{
${ }^{5}$ Arif Afandi, "Gus Ipul Launching Majalah Auleea, Edisi 05 November 2014," PT. Aula Media NU, Majalah Auleea Edisi 28 bulan Oktober 2016, 1

${ }^{6}$ Ayunda Rahma, Redaktur Pelaksana, Wawancara oleh Penulis, Surabaya, 12/10/2016.

7 Joe Runtiko, Wakil Pimpinan Redaksi, Wawancara oleh Penulis, Surabaya, 12/10/2016.

8 Riyamah Hartono, Wakil Pemimpin Perusahaan, Wawancara oleh Penulis, Surabaya 16/04/2017
} 
menjadi majalah skala nasional ini mengambil ceruk pasar wanita spesifik cosmopolitan. ${ }^{9}$

Sisi lain majalah Auleea selain sebagai lahan bisnis juga sebagai saluran media dakwah yang berisi tentang permasalahan fikih Islam, pendidikan anak, fashion perempuan muslimah, serta cerita hikmah berkenaan tentang kehidupan rumah tangga perempuan muslimah. Isi majalah Auleea menjadi sarana dakwah NU untuk merubah pandangan perempuan NU agar lebih modern dalam hal pengetahuan dan penampilan. ${ }^{10}$ Berdasarkan penuturan Ibu Riyamah Hartono selaku wakil direktur PT. Auleea Media NU, majalah Auleea adalah majalah komunitas, pemilihan target pasar tersebut dikarenakan orientasi Auleea yang ingin mengandalkan pembeli yang berlangganan, bukan pembeli yang adhoc, sehingga setiap pelanggan akan diberikan penawaran lebih jika berlangganan mulai dari 3 bulan, 6 bulan dan satu tahun. ${ }^{11}$

Salah satu cara yang dilakukan adalah dengan merangkul banyak komunitas wanita salah satunya adalah Muslimat dan Fatayat NU yang ada di kabupaten/kota, hijabers community Surabaya, pengajian-pengajian wanita yang ada di masjid dan di perumahan. Majalah yang memutuskan belum merambah pasar online ini, melakukan kerjasama dengan hiijabers community untuk menjadi kontributor di majalah

\footnotetext{
${ }^{9}$ Riyamah Hartono, Wawancara.

10 Ibid.

11 Ibid.
}

sekaligus meminta mereka untuk membeli majalah tersebut setiap bulan. ${ }^{12}$ Dalam mengenalkan brand-nya, Majalah Auleea juga melakukan event-event besar, seperti mengadakan pemilihan putri Auleea. ${ }^{13}$ Dalam pemilihan ini banyak diikuti oleh beberapa remaja dari berbagai universitas seperti Universitas Islam Negeri Sunan Ampel Surabaya, Universitas Surabaya, Institut Teknologi 10 November Surabaya, dan lain-lain. Isi kegiatan ini berupa ajang pemilihan putriputri Nahdlatul Ulama yang memiliki keahlian tertentu. Seperti pemenang 2016 pemilihan Putri Auleea memiliki kemampuan tiga Bahasa. ${ }^{14}$

Berdasarkan pada pemaparan di atas menunjukkan bahwa majalah Auleea menggunakan banyak varian komunikasi pemasaran untuk mengenalkan produknya agar lebih dikenal oleh pasar sasar. Banyaknya majalah yang juga menyasar kalangan muslimah akan menjadi tantangan tersendiri bagi majalah baru seperti majalah Auleea. Ketercapaian yang dialami oleh majalah Auleea harapannya bisa menjadi pelajaran bagi organisasi dakwah yang bergerak dalam bidang sejenis, utamanya dalam memasarkan produk media cetaknya.

Studi-studi sebelumnya terkait strategi komunikasi pemasaran, di antaranya adalah, pertama, tesis berjudul "Strategi Komunikasi Pemasaran Majalah Islam Studi Kasus pada Majalah Islam dengan Segmen Remaja Majalah Annida dan

\footnotetext{
12 Joe Runtiko, Wawancara.

13 Ibid.

${ }^{14}$ Ayunda Rahmah, Wawancara.
} 
Majalah Muslimah." Studi tersebut mencari faktor-faktor keberhasilan dari majalah Annida dan majalah Muslimah yang bisa bersaing dan survive di pasaran. Hasil penemuannya menyatakan bahwa faktor penentuan sasaran yang dibidik secara spesifik, produk yang mempunyai identitas khas, penetapan harga yang sangat terjangkau, adanya jalur distribusi khusus, serta berbagai kegiatan promosi yang mendukung identitas majalah Annida dan majalah Muslimah. ${ }^{15}$

Kedua, skripsi berjudul "Strategi Komunikasi Pemasaran Majalah Ummi (PT. Insan Media Pratama) dalam Meningkatkan Penjualan Periode tahun 2012." Penelitian tersebut berfokus pada proses pembuatan strategi komunikasi pemasaran dengan unit analisis streght, weakness, oportunity, threat (SWOT) dan analisis segmentation, targetting, positioning (STP) hingga munculnya ragam bauran pemasaran yang meliputi iklan, promosi penjualan, sponsorship, hubungan masyarakat dan pemasaran langsung dan dan penjualan pribadi. Terdapat kesamaan objek yang dikaji, yaitu strategi komunikasi pemasaran, akan tetapi subjeknya berbeda. ${ }^{16}$ Ketiga, artikel dalam Jurnal Pemasaran Kompetitif, "Strategi Komunikasi Pemasaran Harian Republika untuk

\footnotetext{
${ }^{15}$ Mahasiswa pasca sarjana UI, "Strategi komunikasi pemasaran majalah Islam Studi kasus pada majalah Islam dengan segmen remaja majalah Annida dan majalah Muslimah" (Tesis--Universitas Indonesia), abstrak.

16 Yudith Pradita, "Strategi komunikasi pemasaran majalah Ummi (PT. Insan Media Pratama) dalam meningkatkan penjualan periode tahun 2012" (Skripsi-Universitas Mercubuana Jakarta, Jakarta, 2013), v.

${ }^{17}$ Rini Dianti, "Strategi Komunikasi Harian Republika untuk Menciptakan Kepuasan Pelanggan: Studi
}

Menciptakan Kepuasan Pelanggan (Studi Kasus pada Harian Umum Republika)." Studi tersebut menunjukkan bahwa strategi komunikasi pemasaran harian masih menggunakan elemen komunikasi pemasaran konvensional dan mengharapkan bahwa harian ini harus terus melakukan inovasi-inovasi baru untuk bisa menyesuaikan zaman. ${ }^{17}$

Keempat, Skripsi yang berjudul "Strategi Komunikasi Pemasaran dalam Bidang Promosi: Studi Deskriptif Kualitatif Strategi Komunikasi Pemasaran dalam Bidang Promosi terhadap Koran Sindo Jatim di Surabaya." Studi ini menghasilkan kesimpulan Koran Sindo menggunakan bauran promosi dengan melakukan penjualan personal, promosi penjualan dengan memberikan bonus tabloid Genie, serta mengembangkan event baik onair maupun offair. ${ }^{18}$ Kelima, skripsi berjudul "Strategi Komunikasi Pemasaran Harian Jogja dalam Memasuki Pasar di Jogjakarta." Studi ini menghasilkan kesimpulan bahwa harian ini menggunakan seluruh bauran pemasaran seperti iklan di TV lokal, radio, billboard, dan spanduk. Sedangkan dalam penjualan mengandalkan agen dan pengecer/pedagang jalanan. Untuk public relation dengan mensponsori berbagai kegiatan. ${ }^{19}$

Kasus pada Harian Umum Republika", Jurnal Pemasaran Kompetitif, Vol. I, No. 02/ Januari 2018) 132.

${ }^{18}$ Amanda Septi Rachmawati, "Strategi Komunikasi Pemasaran dalam Bidang Promosi: Studi Deskriptif Kualitatif Strategi Komunikasi Pemasaran dalam Bidang Promosi terhadap Koran Sindo Jatim di Surabaya" (Skripsi, Universitas Pembangunan Negara Jatim, Surabaya, 2013), xiv.

19 Aris Wahyu, "Strategi Komunikasi Pemasaran Harian Jogja dalam Memasuki Pasar di Jogjakarta," 


\section{Komunikasi Pemasaran}

\section{Definisi Komunikasi Pemasaran}

Philip Kotler berpendapat bahwa komunikasi pemasaran adalah sarana yang digunakan perusahaan dalam upaya untuk menginformasikan, membujuk, dan mengingatkan konsumen secara langsung atau tidak langsung tentang produk dan merek yang mereka jual. Dalam pengertian tertentu, komunikasi pemasaran menggambarkan "suara" merek dan merupakan sarana yang dapat digunakan untuk membangun dialog dan hubungan dengan konsumen. ${ }^{20}$ Komunikasi pemasaran banyak digunakan oleh pemasar dikarenakan komunikasi memiliki banyak fungsi yakni konsumen dapat diberitahu atau ditunjukkan tentang cara menggunakan produk, pengetahuan tentang sasaran produk dan waktu penggunaan produk. Konsumen dapat belajar membuat produk dan perusahaan bisa memenuhi kebutuhan dari pelanggan sehingga bisa dijadikan pijakan untuk menetapkan evaluasi pemasaran. $^{21}$

Komunikasi pemasaran juga memungkinkan perusaaan menghubungkan merek-merek mereka dengan merek produk lain, tempat, acara khusus, pengalaman merek, perasaan, dan barang. Komunikasi pemasaran juga dapat berkontribusi pada kekuatan (equity) merek dengan membangun

(Skripsi, UIN Sunan Kalijaga, Jogjakarta, 2009), 72 73.

20 Philip Kotler, Manajemen Pemasaran Edisi Dua Belas Jilid 2(Indonesia: PT. Indeks, 2007), 145

21 Ibid., 204.

22 Ibid., 205. merek dalam ingatan dan menciptakan citra merek. Setiap kontak akan menciptakan satu kesan yang dapat menguatkan atau melemahkan pandangan pelangan terhadap perusahaan. ${ }^{22}$

Aktivitas komunikasi pemasaran berkontribusi pada ekuisitas merek melalui banyak cara meliputi dengan menciptakan kesadaran akan merek, menghubungkan asosasi yang tepat dengan gambar merek dalam memori konsumen, mendapatkan penilaian dan perasaan merek yang positif dan memfasilitasi satu tautan konsumen merek yang kuat. ${ }^{23}$ Pengembangan teori komunikasi pemasaran, untuk mengimplementasikan strategi komunikasi pemasaran empat pokok tahapan yakni mengidentifikasi pasar sasaran, menentukan tujuan komunikasi, merancang pesan, memilih saluran komunikasi. ${ }^{24}$

\section{Mengidentifikasi Pasar (Audiens)} Sasaran

Langkah yang paling kritis dalam proses pengembangan komunikasi pemasaran efektif adalah menentukan audiens sasaran. Karena langkah ini akan memengaruhi keputusan mnegenai apa, bagaimana, kapan, di mana, dan kepada siapa pesan akan disampaikan. Yang biasa dijadikan audiens sasaran utama dapat

\footnotetext{
${ }^{23}$ Ibid., 205.

${ }^{24}$ Fandy Tjiptono, Gregorius Chandra, Dadi Adriana, Pemasaran Strategi: Mengupas Topik Utama Pemasaran Strategic, Branding Strategi, Costumer Satisfaction, Strategi Kompetitif, Hingga $E$ Marketing (Yogyakarta: C.V. Andi Offset, 2008), 509.
} 
beraneka macam. ${ }^{25}$ Pertama, pembeli potensial, pengguna saat ini, deciders (orang yang membuat keputusan pembelian), atau influencers (orang yang memengaruhi keputusan dan pilihan pembelian). Kedua, individu, kelompok, masyarakat tertentu atau masyarakat umum. ${ }^{26}$ Dengan teridentifikasinya auidiens sasaran, pemasar harus dapat pula mengidentifikasi persepsinya terhadap citra perusahaan, citra produk, dan citra para pesaing. ${ }^{27}$

\section{Menentukan Tujuan Komunikasi Pemasaran}

Tujuan komunikasi dapat diarahkan pada pengembangan respon yang diharapkan pada tiga tahap yakni tahap kognitif, tahap afektif, dan tahap konatif. Ketiga jenis tahapan yang dikenal pula dengan istilah "learn-feel-do" ini dijadikan dasar dalam pengembangan model hirarki respon (response hierarchy model). Salah satu model yang paling populer adalah model AIDA (attention, interest, desire, action), yaitu attention mencerminkan tahap kognitif, interest dan desire merupakan tahap afektif. Sedangkan action merupakan wujud dari tahap perilaku/konatif. ${ }^{28}$

\section{Merancang Pesan Komunikasi Pemasaran}

Perancangan pesan berkaitan erat dengan empat isu utama yang salin terkait yakni pesan apa yang ingin disampaikan yakni menyangkut tiga macam daya tarik atau unique selling propotion (USP) yang ditawarkan kepada para audiens. Daya tarik rasional, emosional, dan moral. ${ }^{29}$ Daya tarik rasional menekankan manfaat produk, seperti kualitas, harga, value, atau kinerja. Konsumen industrial merupakan tipe pelanggan yang sangat responsif terhadap daya tarik rasional. Daya tarik emosional berusaha memanfatkan emosi positif (seperti humor, cinta, rasa bangga, rasa senang, dan sejenisnya) atau emosi negatif (seperti rasa takut, rasa bersalah, malu, tegang, sedih, was-was, dan seterusnya) untuk memotivasi pembelian. Daya tarik emosi positif banyak dimanfaatkan dalam mengomunikasikan merek-merek eksklusif dan prestisius, seperti Harley Davidson, Rolex, Roll-Royce, Mercedes, Prada, Gucci, dan lain-lain. Daya tarik emosi negatif dapat dipakai untuk mendorong seseorang agar berbuat sesuatu, maupun mendorong seseorang agar menghentikan kebiasaan buruknya. Sementara itu, daya tarik moral (moral appeals) berfokus pada upaya mendorong konsumen agar mendukung dan berpartisipasi dalam berbagai aktivitas social.

Cara menyampaikan pesan yang logis sangat diperlukan dalam melakukan komunikasi. Hal ini berkaitan dengan penarikan sebuah kesimpulan, one sided arguments vs two sided arguments dan urutan presentasi pesan. Pilihan dalam hal penarikan kesimpulan ada dua, yaitu membiarkan audiens menyimpulkan sendiri pesan yang dibaca/ditontonnya atau perusahaan yang menegaskan kesimpulan untuk para audiens. Contohnya ada majalah yang secara tegas

\footnotetext{
${ }^{28} \mathrm{lbid}$.

29 Ibid., 510.
} 
dan eksplisit menyebutkan target audiensnya misalnya bacaan khusus remaja pria, remaja putri, wanita dewasa dan lain-lain. Namun ada pula yang tidak menegaskan hal seperti itu dan sebaliknya kadang malah membuatnya mengambang (stimulus ambiguity). One side hanya menegaskan keunggulan produk. Sedangkan two sided arguments menyebutkan keunggulan sekaligus kelemahan produk. Two sides arguments akan lebih cocok bagi audiens yang tingkat pendidikannya tinggi. Sehingga dapat lebih objektif dalam menilai pesan komunikasi pemasaran. ${ }^{30}$ Selain penyampaian secara lisan, cara menyampaikan secara simbolis (format pesan) digunakan dalam menyampaikan pesan yaitu menyangkut headline, copy, ilustrasi dan warna iklan (iklan di media cetak). Kata-kata, kualitas suara, dan vokalisasi (iklan di radio), katakata, warna, ilustrasi, kualitas suara, headlines, copy dan body language (iklan di TV), warna, tekstur, ukuran, bentuk, dan aroma (produk atau kemasa). ${ }^{31}$

Pihak yang menyampaikan pesan, terutama menyangkut kredibilitas penyampai pesan. Sumber pesan yang atraktif atau populer cenderung dapat meraih perhatian dan ingatan yang lebih besar dibandingkan orang awam. Itulah sebabnya kalangan selebriti banyak dimanfaatkan dalam iklan. Penggunaan sumber pesan yang kredibel biasanya akan memiliki daya persuasif yang besar. Kredibilitas umber pesan dipengaruhi oleh tiga faktor. Pertama, expertise, yaitu pengetahuan khusus yang dimiliki komunikator untuk mendukung dan

30 lbid., 510.

31 lbid., 511. melandasi klaimnya. Kedua, trustsworthiness, berkenaan dengan persepsi audiens terhadap objektivitas dan kejujuran sumber pesan. Teman dan keluarga akan lebih dipercaya ketimbang orang asing atau wiraniaga. Orang yang tidak dibayar untuk mendukung sebuh produk juga akan lebih dipercaya dibandingkan orang yang dibayar khusus untuk itu. Ketiga, likability yang menggambarkan daya tarik sumber pesan, misalnya populer, cantik, ganteng, humoris, berpostur atletis dan lain-lain. ${ }^{32}$

\section{Memilih Saluran Komunikasi Pemasaran}

Saluran komunikasi pemasaran terdiri dari dua macam, yaitu saluran komunikasi personal dan saluran komunikasi nonpersonal. Saluran komunikasi personal terdiri atas dua orang atau lebih orang yang saling berkomunikasi secara langsung, baik dengan tatap muka, melalui telepon, via email, online chatting, maupun dalam bentuk presentasi. Saluran komunikasi personal dapat diklasifikasikan menjadi: advocate channels (wiraniaga yang menghubungi konsumen), expert channels (pakar independen yang membuat pernyataan tertentu kepada konsumen sasaran), dan social channels (tetangga, teman, keluarga, dan rekan kerja). Secara umum, saluran komunkasi personal memainkan peran penting dalam dua situasi utama. Pertama, pembelian produk yang harganya mahal, berisiko tinggi, dan pembeliannya jarang dilakukan. Kedua, situasi pembelian produk yang berkaitan dengan status atau selera pemakai. Dalam situasi-situasi tersebut

32 Ibid., 511-512. 
konsumen cenderung akan mempertimbangkan pendapat sumber personal ini. Yang paling efektif adalah social channels atau yang kerapkali disebut pula komunikasi gethok tular (word of mouth communication). ${ }^{33}$

Personal selling sangat efektif dalam tahap pembentukan preferensi keyakinan, dan tindakan pembeli. Keunggulan utama alat komunikasi pemasaran yang satu ini adalah: (1) personal confrontation, artinya terjadi relasi langsung dan interaksi antara dua atau lebih pihak, yang masing-masing pihak dapat saling mengamati reaksi masing-masing; (2) cultivation, artinya memungkinkan terjalinnya hubungan yang akrab antara wiraniaga dan pembeli dan (3) response, yaitu situasi yang seolah-olah harus mengharuskan pembeli untuk mendengar, memerhatikan, atau menanggapi presentasi wiraniaga. ${ }^{34}$

Direct \& online marketing mencakup beraneka ragam bentuk, seperti direct print and reproduction (contohnya $C D$ ROM), direct-response TV dan radio. Keunikan utamanya meliputi: (1) nonpublik communication artinya pesan disampaikan kepada orang tertentu dan tidak bersifat massal; (2) costumized, artinya pesan dapat dirancang dan disiapkan khusus untuk menarik pelanggan individual yang dituju; (3) up to date artinya pesan dapat disiapkan secara sangat cepat; dan (4) interactive, artinya pesan dapat diubah sesuai dengan respons pelanggan. Online marketing bahkan

\footnotetext{
33 Ibid., 512-513.

34 Ibid., 517.

35 Ibid., 518.

36 lbid., 513
}

memiliki keunggulan tambahan, seperti realtime (respons langsung), komunikasi global 24 jam, fleksibilitas tinggi, dan seterusnya. ${ }^{35}$

Saluran komunikasi nonpersonal meliputi media atmospheres dan event. Media terdiri atas media cetak (seperti koran, majalah, direct mail. Media siaran seperti radio dan TV), media elektronik (seperti audiotape, videotape, videodisk, CD ROM, web page), dan atmospheres berupa suasana kantor, toko, dan ruang tunggu yang dirancang sedemikian rupa sehingga dapat menciptakan atau memperkuat pembelajaran konsumen terhadap pembelian produk. ${ }^{36}$ Menurut kotler saluran komunikasi nonpersonal meliputi media, promosi penjualan, acara khusus atau event dan pengalaman, dan hubungan masyarakat. ${ }^{37}$ Event adalah acara atau peristiwa-peristiwa yang dirancang untuk mengomunikasikan pesan tertentu kepada audiens sasaran. Diantaranya konferensi pers, grand openings, sponsorship kegiatan olahraga, sponshorship kegiatan musik dan lainlain. ${ }^{38}$

Iklan lebih bersifat monolog. Iklan dapat dimanfaatkan secara efektif untuk membangun citra jangka panjang produk maupun perusahan, memicu pembelian segera (terutama jika dipadukan dengan promosi penjualan), dan menjangkau konsumen yang lokasinya tersear secara geografis. Dalam beberapa tahun terakhir, sejumlah bentuk media iklan baru

\footnotetext{
37 Philip Kotler, Manajemen Pemasaran Edisi Dua Belas Jilid 2(Indonesia: PT. Indeks, 2007), 224.

38 Tjiptono, Chandra, Adriana. Pemasaran Strategi: Mengupas., 513.
} 
bermunculan dan berkembang pesan, diantaranya advertorial. ${ }^{39}$

Promosi penjualan menggunakan sejumlah alat (seperti diskon, kontes, undian, kupon, premium, produk sampel, dan lain-lain) untuk menawarkan tiga manfaat pokok yakni: (1) komunikasi, yaitu memberikan informasi yang dapat menarik perhatian konsumen agar tertarik untuk membeli produk; (2) insentif, berupa kontribusi, konsesi, atau dorongan yang dapat bernilai tambah bagi pelanggan; (3) invitasi, yang mengharapkan agar konsumen segera melakukan transaksi pembelian. Promosi penjualan cenderung efektif untuk menciptakan respons pembeli yang kuat dan segera, mendramatisasi penawaran produk dan mendongkrak penjualan dalam jangka pendek. ${ }^{40}$

Public relations memiliki sejumlah keunggulan, diantaranya: (1) kredibilitas tinggi, (2) kemampuan menjangkau audiens yang cenderung menghindari wiraniaga dan iklan; serta memungkinkan untuk mendramatisasi perusahaan atau produk. Pemanfaatan public relations mulai banyak dilakukan dalam dua dasawarsa terakhir, walaupun sayangnya masih banyak perusahaan yang belum mengoptimalkan fungsi PR. Yang banyak dijumpai justru departemen PR hanya sebatas melakukan jumpa pers, menyelenggarakan acara peluncuran produk baru, atau menangani complain pelanggan. Sesungguhnya potensi PR jauh lebih dari itu. ${ }^{41}$

\footnotetext{
39 lbid., 516.

40 Ibid., 517.

41 lbid., 517.
}

\section{Metodologi}

Tujuan penulisan ini adalah mendeskripsikan

implementasi komunikasi pemasaran yang dilakukan oleh Majalah Auleea dalam mengenalkan produknya di segmen wanita muslimah. Pendekatan yang digunakan adalah kualitatif. Sedangkan data yang akan didapatkan adalah data teks yang dipaparkan secara holistik (menyeluruh, tidak dapat dipisah-pisahkan). ${ }^{42}$ Data-data tersebut meliputi data tentang tujuan komunikasi, pesan komunikasi dan saluran komunikasi yang digunakan untuk menyampaikan pesan Majalah Auleea dengan unit analisis sebagai berikut: (1) tujuan komunikasi pemasaran, (2) pesan komunikasi pemasaran, (3) target pasar/komunikan komunikasi pemasaran (4) media komunikasi (5) komunikator komunikasi pemasaran. ${ }^{43}$

Jenis data yang digunakan adalah data berupa data teks hasil wawancara dan studi dokumen dari beberapa sumber data serta hasil pengamatan penulis pada salah satu gerai majalah Auleea. Data tersebut dibagi data primer dan data sekunde. Data primer didapatkan dari direksi dan karyawan Majalah Auleea sedangkan data sekunder didapatkan dari dokumendokumen yang ada di media online dan Majalah Auleea dan Aula.

Pengambilan data tersebut dilaksanakan selama bulan April - Mei 2017 di kantor Majalah Auleea serta di booth majalah Aula dan Auleea di pameran perguruan tinggi JX Expo Surabaya. Adapun konseptualisasi dan indikator unit analisis

\footnotetext{
42 Sugiyono, Metode Penelitian Kombinasi (Mixed Methods) (Bandung: Penerbit Alfabeta, 2015), 287. 43 Ibid., 147.
} 
dalam studi ini dijelaskan dalam tabel

berikut:

Tabel 1- Konseptualisasi dan Indikator Unit Analisis

\begin{tabular}{|c|c|c|}
\hline Unit Analisis & Konseptualisasi & Indikator \\
\hline $\begin{array}{l}\text { Audiens/Sasaran } \\
\text { komunikasi }\end{array}$ & $\begin{array}{l}\text { Pasar yang diajak komunikasi } \\
\text { meliputi pasar potensial dan } \\
\text { individu, kelompok, publik } \\
\text { tertentu atau umum. Pasar } \\
\text { potensial adalah pengguna } \\
\text { saat ini. }\end{array}$ & $\begin{array}{l}\text { - Yang dikunjungi pada saat personal selling } \\
\text { - Yang biasa mengajukan pertanyaan untuk } \\
\text { berlanggan } \\
\text { - Pihak yang datang menuju gerai majalah } \\
\text { Auleea }\end{array}$ \\
\hline $\begin{array}{l}\text { Tujuan } \\
\text { komunikasi }\end{array}$ & $\begin{array}{l}\text { Target yang dituju dalam } \\
\text { melakukan } \\
\text { pemasaran }\end{array}$ & $\begin{array}{l}\text { - Target kognisi: pelanggan tahu bahwa ada } \\
\text { majalah Auleea } \\
\text { - Target afeksi: orang senang dengan majalah } \\
\text { Auleea } \\
\text { - Target konasi: tindakan pembelian }\end{array}$ \\
\hline $\begin{array}{l}\text { Pesan } \\
\text { komunikasi }\end{array}$ & $\begin{array}{l}\text { - Hal yang disampaikan } \\
\text { kepada pelanggan atau } \\
\text { pengunjung gerai majalah } \\
\text { Auleea } \\
\text { - Simbol-simbol yang } \\
\text { menunjang komunikasi } \\
\text { - Tahapan pesan yang } \\
\text { disampaikan oleh pemasar } \\
\text { majalah Auleea. }\end{array}$ & $\begin{array}{l}\text { - Teks lisan yang disampaikan pemasar kepada } \\
\text { pelanggan selama event berlangsung, suara } \\
\text { iklan di radio, tulisan, gambar yang } \\
\text { mengiklankan majalah Auleea } \\
\text { - Simbol berupa warna, desain gerai, atau } \\
\text { atribut pemasaran } \\
\text { - Urutan pesan yang disampaikan kepada } \\
\text { pelanggan secara langsung } \\
\text { - Gambar yang ditonjolkan atau diperbesar } \\
\text { - } \text { - Falam iklan } \\
\text { - Promat acara pada saat personal event }\end{array}$ \\
\hline $\begin{array}{l}\text { Saluran } \\
\text { komunikasi }\end{array}$ & $\begin{array}{l}\text { Cara yang dilakukan dalam } \\
\text { melakukan pemasaran } \\
\text { meliputi public relation, } \\
\text { event, personal selling, dan } \\
\text { lain-lain }\end{array}$ & $\begin{array}{l}\text { - Sarana yang digunakan untuk bertemu } \\
\text { pelanggan secara langsung } \\
\text { - Sarana yang digunakan untuk menjelaskan } \\
\text { produk baru majalah Auleea }\end{array}$ \\
\hline $\begin{array}{l}\text { Komunikator } \\
\text { pemasar }\end{array}$ & $\begin{array}{l}\text { Subjek yang melakukan } \\
\text { komunikasi langsung dengan } \\
\text { pelanggan }\end{array}$ & $\begin{array}{l}\text { - Orang yang menyampaikan komunikasi } \\
\text { - Pilihan tempat radio atau media cetak yang } \\
\text { digunakan majalah Auleea } \\
\text { - Komunikator didengarkan oleh pelanggan } \\
\text { pada saat berbicara } \\
\text { - Pelanggan menanggapi komunikasi dengan } \\
\text { wajah senang }\end{array}$ \\
\hline
\end{tabular}

Kredibiltas data dilakukan dengan triangulasi sumber dan triangulasi teknik. Triangulasi sumber berfungsi untuk menguji kredibilitas data dilakuakan dengan cara mengecek data yang diperoleh melalui beberapa sumber. ${ }^{44}$ Sedangkan triangulasi teknik yakni untuk menguji kredibilitas dengan cara

44 Ibid., 370. 
mengecek data dari sumber yang sama akan tetapi teknik yang digunakan berbeda. ${ }^{45}$ Data didapatkan dari hasil wawancara antar pengurus Majalah Auleea akan diuji kesamaan dan perbedaan satu dengan yang lain dan melakukan triangulasi teknik yakni pengkroscekan data yang didapatkan melalui wawancara dengan dokumen yang meliputi Majalah Auleea, sumber berita website NU online, serta dokumen video youtube yang memuat pernyataan pimpinan redaksi Majalah Auleea kepada TV9 yang merayakan ulang tahun televisinya. Teknik analisis yang dilakukan adalah dengan menggunakan Miles dan Huberman, yakni melakukan reduksi data menyesuaikan dengan sub variabel yang dibutuhkan dan melakukan klasifikasi berdasarkan unit analisis dari strategi komunikasi pemasaran. Data tersebut kemudian diinterpretasi dan disimpulkan. ${ }^{46}$

\section{Sekilas Majalah Auleea}

Majalah Auleea adalah majalah yang terbit setiap bulan dan penerbitan pertama adalah bulan Mei tahun 2014, majalah ini diterbitkan oleh PT. Aula Media NU yang merupakan salah satu badan usaha dari Pimpinan Wilayah Nahdlatul Ulama Jawa Timur. Selama ini, PT. Aula Media NU berdiri sejak tahun 1977 dengan menerbitkan majalah Aula yang menyasar segmen santri, kiai dan pemerhati. Majalah Auleea beralamatkan di Jalan Masjid Al-Akbar Nomor 9

45 Ibid., 371.

46 lbid., 383.

47 Arif Afandi, "Lahir dari Rahim Aula," Auleea (November), 3.
Surabaya. Auleea ini sengaja diterbitkan untuk melayani santri perkotaan tanpa meninggalkan santri desa sebagai basis utama pembaca Auleea. Majalah ini berusaha menjadi jembatan budaya antara santri pedesaan dan santri kota. Majalah Auleea berusaha untuk menyediakan bacaan untuk keluarga santri tanpa meninggalkan akarnya. ${ }^{47}$

Asal mula majalah ini diawali dari pertemuan antara Arif Afandi sebagai pemimpin umum Majalah Aula di undang untuk memberikan materi dalam acara Fatayat NU Jatim. Ketika itu, muncul tawaran untuk bekerjasama membuat majalah baru untuk keluarga. Sebab, selama ini majalah Aula yang kini oplahnya 25.000 eksemplar itu banyak menampung aspirasi para santri dan pengamat saja, sedangkan aspirasi perempuan tidak banyak dimuat. Artinya, pembaca Ibu-lbu yang jumlahnya makin banyak belum terakomodasi ${ }^{48}$. Tawaran yang disampaikan oleh Arif Afandi itu mendapatkan respon yang positif dari pengurus Fatayat NU Jawa Timur. Maka lahirlah Majalah Auleea. Majalah keluarga muslimah pertama yang dilahirkan oleh PT. Aula Media NU dan berhaluan Ahlussunah Waljamaah An-Nahdliyah. ${ }^{49}$ Majalah ini banyak mengeksplore gaya hidup muslimah modern, muslimah yang rahmatan lil alamiin, memberikan rahmat bagi sekalian alam. Bukan muslimah yang ekslusif, tapi muslimah yang inklusif. Muslimah yang ramah dengan sekitarnya,

\footnotetext{
${ }^{48}$ Ibid.

49 Ibid.
} 
yang tidak alergi dengan pembaharuan, meski berpegang teguh pada aqidahnya ${ }^{50}$.

Majalah Auleea bertekad akan selalu menampilkan hal baru, yang berkembang di dalam kaum muslimah, baik itu dalam hal pandangan, sikap dan perilaku. Semua itu kemudian dilihat dari sudut pandang sistem nilai keagamaan yang merujuk pada Alquran, hadis, ijmak para kiai, dan qiyas. ${ }^{51}$ Majalah ini dipatok dengan harga eceran sebanyak Rp. 25.000 untuk daerah Jawa, sedangkan di luar pulau Jawa dipatok dengan harga Rp. 30.000. Bagi pelanggan yang berlangganan akan diberikan potongan harga, untuk langganan 6 bulan dengan harga Rp. 140.000, dan untuk luar Jawa dengan harga Rp. 175.000. Pelanggan yang ada di pulau Jawa jika berlangganan selama satu tahun akan mendapatkan harga Rp. 270.000, sedangkan yang ada di luar Pulau Jawa mendapatkan harga Rp. 325.000 .

\section{Implementasi Strategi Komunikasi Pemasaran Majalah Auleea}

\section{Sasaran Komunikasi Pemasaran}

Sasaran komunikasi terdapat dua macam, yakni pembeli potensial dan individu, kelompok, publik tertentu atau publik umum. Pembeli potensial adalah pengguna saat ini. deciders (orang yang membuat keputusan pembelian) atau influencers (orang yang mempengaruhi keputusan dan pilihan pembelian). ${ }^{52}$

\footnotetext{
${ }^{50}$ Arif Afandi, Gus Ipul Launching Majalah Auleea, Auleea (November 2014), 3.

51 Ibid. 3.
}

Sesuai dengan tagline yang disebutkan oleh majalah Auleea. Sasaran komunikasi adalah keluarga muslimah, yang terdiri dari suami, istri, dan anak. Akan tetapi diantara anggota keluarga tersebut yang menjadi sasaran utamanya adalah wanita bisa istri atau anak perempuan, sedangkan suami merupakan sasaran komunikasi sekunder. Suami bisa menjadi target sasaran bertujuan agar suami membelikan majalah untuk istri. Hal ini dikarenakan suami bisa sebagai influencers agar menyuruh istri untuk membaca majalah tersebut. sedangkan anak perempuan adalah pihak yang juga berkepentingan terhadap rubrik-rubrik masalah perempuan seperti fikih perempuan, atau fashion wanita yang menjadi tren masa kini.

Dari sudut pandang ekonomi, keluarga yang disasar adalah keluarga dari kalangan kelas menengah, dan kalangan menengah atas. Hal ini dikarenakan majalah ini dipatok dengan Rp. 25.000,/eksemplar. Harga yang tidak murah. Dengan uang tersebut tentu orang akan lebih baik digunakan untuk beli beras sebanyak dua kilogram atau minyak goreng dibandingkan digunakan untuk membeli majalah. Pasar sasaran dengan ekonomi yang berkecukupan tidak bisa menjadi jaminan akan membeli majalah. Maka karakter dari pasar sasar adalah mereka suka membaca atau suka mendapatkan pengetahuan baru. Berdasarkan penuturan Bu Riyamah menyebutkan bahwa wanita yang tidak memiliki kesadaran terhadap pendidikan

\footnotetext{
52 Tjiptono, Chandra, Adriana, Pemasaran Strategi: Mengupas., 509.
} 
dan suka membaca, mereka lebih memilih membeli harga tas yang bernilai jutaan dari pada membeli majalah Auleea yang hanya Rp. 25.000,- per eksemplar.

Selain itu, Sasaran komunikasi tidak hanya keluarga, sasaran juga bisa berupa publik umum. Dalam hal ini sasaran majalah Auleea adalah komunitas perempuan muslim. Komunitas ini adalah komunitas yang berkaitan dengan perempuan. Bisa perempuan remaja atau perempuan yang sudah menikah dan memiliki anak. Hal ini dikarenakan isi dari majalah Auleea banyak rubrik tentang kesukaan perempuan muslim seperti parenting, fikih wanita, dan lain-lain. Komunitas perempuan muslim juga bisa berasal dari kalangan berpendidikan dan memperhatikan fashion masa kini. Lembaga pendidikan seperti pesantren juga menjadi target pasar dari majalah Auleea. Hal ini dikarenakan pesantren merupakan pasar yang potensial. Jumlah santriwatinya banyak. Sehingga Auleea juga menyasar pesantren dan mengusahakan agar didalam pesantren terdapat agen majalah Auleea.

NU juga merupakan pasar yang potensial. Ini dikarenakan majalah ini adalah majalahnya orang NU akan tetapi badan otonom yang potensial adalah Fatayat dan Muslimat NU. Menurut Ibu Riyamah, Pak Arif Affandi selaku direktur majalah Auleea ingin mengangkat harkat dan martabat remaja Fatayat dan Muslimat. Kalau ada wanita, ada mulai dari pelajar $\mathrm{NU}$, mahasiswa, sampai ada Fatayat, maka sasaran majalah itu Fatayat.

53 Riamah Hartono, Wawancara, Surabaya, 19 April 2017.
Majalah ini ingin mengenalkan Fatayat Muslimat NU itu lebih moderat oleh karena itu sasaran utamanya adalah untuk keluarga muslim yang hedon dan perkotaan. Berikut penuturan Ibu Riyamah, "Nah ini Iho orang Islam tidak cukup dengan pondok pesantren, kita ingin membuat terobosan bahawa Islam itu universal, bahwa semua muslim bisa diterima secara universal yang sesuai dengan program NU yang nusantara, yang nusantara jadi tidak harus koprot, Islam itu modislah, kehidupan orang muslim di Eropa, wali kota londonnya saja orang muslim, berkarir, kita tidak mau wanita arab, wanita arab sampai sekarang menjunjung kebebasan, karena mereka , masih digodok, didikannya dari eropa satu dua orag pangeran yang mengijinkan hijab, nah kita arahnya karena itu adalah nusantara, NU milik semua." ${ }^{\prime 53}$

Pasar keluarga muslim perkotaan juga ditunjukkan dengan bukti bahwa selama ini yang berlangganan majalah Auleea berasal dari ibu kota kabupaten. Selain itu, agen koran atau majalah lebih banyak di perkotaan.

Selain pasar NU, majalah Auleea juga menyasar kalangan perempuan muslim dari berbagai golongan. Oleh karena itu majalah ini juga mengangkat nilai-nilai universal. Majalah ini tidak banyak menonjolkan ke NU annya sebagaimana majalah Aula. Simbol dari NU juga tidak digunakan oleh majalah ini. Sedangkan majalah Aula lebih banyak menonjolkan ke-NU-annya mulai dari kover majalah 
sudah ditunjukkan bahwa majalah Aula adalah majalahnya orang NU. Dengan adanya kegiatan putri auleea, majalah ini juga concern terhadap pasar perempuan muda yang energik, berwawasan luas, memegang teguh nilai-nilai agama dan modis. Pasar kalangan remaja putri muslim sangat potensial, karena mereka masih mencari jati diri keagamaannya. Dengan adanya majalah Auleea bisa menjadi rule muslim Indonesia. Dengan adanya rubrik tutorial hijab bisa lebih memudahkan para remaja untuk meniru cara berpakaian muslimah yang modern yang sopan tetapi modern.

\section{Tujuan Komunikasi Pemasaran}

Tujuan komunikasi dapat diarahkan dalam tiga tahap yakni tahap kognisi, tahap afeksi, dan tahap konatif. Dalam ilmu pemasaran dijelaskan dengan menggunakan AIDA yakni attention, interest, desire, action. ${ }^{54}$ Tujuan komunikasi majalah Auleea beragam, untuk kalangan warga NU yang ada di Jawa Timur, tujuan komunikasinya dengan melakukan pembelian majalah. Hal ini dikarenakan Majalah Auleea adalah majalah yang berada dibawah PT. Aula Media NU. Perusahaan tersebut merupakan salah satu usaha PWNU Jawa Timur. Ketua redaksi majalah Auleea merupakan ketua Fatayat NU Jawa Timur, sehingga dengan kesamaan tersebut maka target majalah kepada perempuan NU pada tingkat action. Hal ini juga dipertegas bahwa untuk beberapa pengurus Fatayat yang ada di Jawa Timur yang memiliki kapasitas untuk membeli diwajibkan untuk membeli majalah NU tidak hanya itu mereka juga diharapkan bisa menjadi agen majalah Auleea untuk disebarkan kepada anggota-anggotanya. Minimal yang membeli adalah ketua dan wakil ketua yang ada di masing-masing cabang.

Tujuan komunikasi untuk pelanggan wanita muslimah secara umum adalah mengenalkan produk Auleea. Hal ini dilakukan dengan salah satu cara yang dilakukan adalah memberikan brosurbrosur kecil yang berisi tentang sekilas majalah Auleea, harga berlangganan dan juga alamat kantor dan media sosial yang digunakan untuk mengakses majalah Auleea serta kesediaan untuk berlangganan majalah. Bagi warga NU yang sudah membeli majalah Aula dalam melakukan komunikasi juga ditarget untuk melakukan pembelian terhadap majalah Auleea.

Komunikasi yang dilakukan untuk majalah Auleea tidak hanya untuk memasarkan produknya saja. Dengan diterbitkannya majalah Auleea yang mengusung nilai rahmatan lil alamin dengan membranding bahwa wanita muslim itu adalah wanita yang modern dan ditandai dengan penampilan yang modis dan memiliki pengetahuan yang luas juga banyak pertentangan. Pembawaan wanita yang diusung majalah Auleea dianggap keluar dari khitah NU. Oleh karena itu komunikasi yang dilakukan adalah dengan memberi tahukan dampak positif dan negatif warga NU sebagai cerminan seorang muslimah ditengah zaman yang modern. Pihak-pihak yang berbeda

${ }^{54}$ Tjiptono, Chandra, Adriana, Pemasaran Strategi: Mengupas., 509. 
pendapat dengan diterbitkannya majalah Auleea tidak serta merta ditarget untuk melakukan pembelian, meskipun mereka adalah warga NU. Mereka bersikap mau menerima Majalah Auleea terbit juga sudah bagus.

Tujuan komunikasi melalui media iklan berbeda dengan pemasaran secara langsung. Target komunikasi iklan hanya agar para pendengar radio mengerti bahwa ada majalah wanita alternatif untuk muslimah selain majalah-majalah yang sudah pernah terbit sebelumnya. Yang menjadi pertimbangan utama memilih radio sebagai salah satu media iklan adalah agar bisa diketahui oleh ibuibu diluar kota Surabaya. berdasarkan penuturuan Ibu Riyamah Hartono dengan iklan di radio perempuan diharapkan tahu bahwa ada Majalah Auleea. Oleh karena itu syarat pemilihan radio adalah frekuensinya juga berada diluar wilayah kota Surabaya. Sedangkan untuk iklan di majalah Aula juga diharapkan para pembaca Aula membeli majalah Auleea untuk keluarga mereka sebagai sumber bacaan alternatif yang lebih banyak mengupas isu-isu wanita. yang lebih banyak mengakomodasi kepentingan wanita. Target remaja muslim majalah Auleea hanya memahami saja.

\section{Pesan Komunikasi Pemasaran}

Terdapat tiga macam daya tarik pesan yang ditawarkan yaitu daya tarik rasional, emosional, dan moral. ${ }^{55}$ Pasar internal masyarakat NU majalah Auleea lebih menekankan pada kesamaan terhadap organisasi dibandingkan dengan isi produk. hal ini diwujudkan dengan diwajibkannya pengurus Fatayat NU Jawa Timur untuk berlangganan majalah Auleea untuk memajukan perusahaan PWNU. Sebenarnya dengan membeli majalah Auleea ini secara tidak langsung bisa digunakan untuk menambah masukan bagi PWNU Jawa Timur. Rasa kepemilikan organisasi ini bisa menjadi salah satu daya tarik warga NU untuk membeli. Berdasarkan pada data diatas maka dapat disimpulkan bahwa isi pesan yang disampaikan kepada warga NU lebih menonjolkan pesan emosional dibandingkan dengan pesan rasional. Komunikasi saluran langsung majalah ini juga dilakukan dengan mendatangi acaraacara besar yang diadakan oleh badan otonom NU seperti Munas NU yang ada di Jombang, Munas Fatayat yang ada di Surabaya. Hal ini dilakukan untuk memperluas pasar Fatayat tidak hanya di Jawa Timur saja, tetapi bisa merambah di luar Jawa Timur.

Daya tarik rasional dilakukan kepada pelanggan yang memiliki pendidikan yang tinggi, hal ini dilakukan pada saat pertama kali datang di gerai majalah Auleea saat menjadi media partner dalam kegiatan sebagaimana disebutkan diatas. Pesan yang disampaikan adalah pesan keunggulan dan kelemahan dari majalah. Keunggulan dari majalah ini adalah dari kertasnya yang bagus dan glossy, kemudian dari segi isi, majalah ini mengambil sudut pandang yang berbeda dengan majalah lain atau dari internet. Sehingga secara content berbeda dengan isi pada umumnya. Sedangkan untuk ketepatan waktu distribusi memang sedang diupayakan oleh majalah Auleea.

55 Ibid., 510 
Secara isi juga akan lebih difokuskan untuk memenuhi kebutuhan pelanggan. Keunggulan dan kelemahan yang dimiliki tersebut tidak semuanya disampaikan oleh pemasar. Ada pemasar yang menyampaikan keunggulan produk, ada juga pemasar yang lebih menekankan kesamaan mengikuti organisasi Nahdlatul Ulama. Selain itu pemasar juga sering menanyakan alamat rumahnya, disana ada agen atau tidak. Pemasar berusaha untuk membangun kesamaan dengan pelanggan atau calon pelanggan, agar mereka merasa nyaman berbicara denngan pemasar. Hal ini juga menjadi data bagi pemasar untuk memetakan kebutuhan pelanggan. Orientasi menanyakan tentang terdapatnya agen di wilayah tersebut adalah untuk meminta calon pelanggan tidak hanya membeli tetapi menjadi agen majalah Auleea kepada teman-teman kerja atau tetangganya. Pesan pada iklan majalah Auleea di majalah Aula lebih menekankan pada bentuk fisik majalah Auleea dengan memperlihatkan kover, selain itu brand sebagai bacaan keluarga muslim modern masa kini. Tak lupa alamat serta kontak yang bisa dihubungi untuk melakukan pemesanan majalah. Masa terbit juga disebutkan dalam majalah.

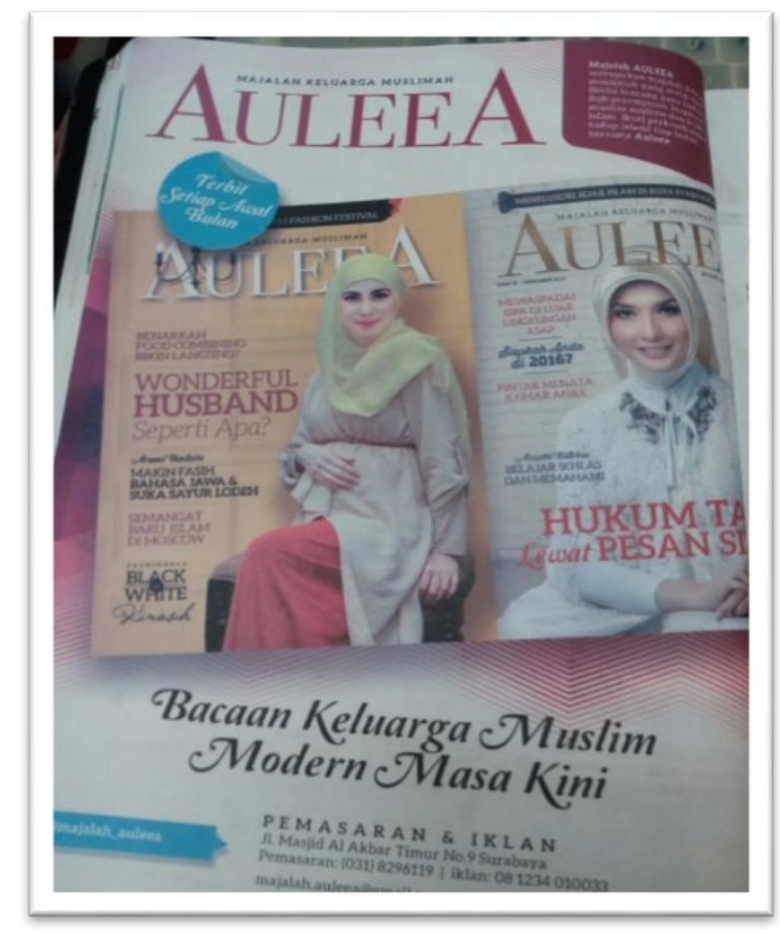

Gambar 1 - Iklan Majalah Auleea di Majalah Aula

Pesan iklan majalah Auleea lebih mengarah pada pemahaman sekilas mengenai majalah Auleea. Promosi majalah yang mendorong untuk segera membeli, tidak disebutkan oleh pihak Auleea. Hal ini menunjukkan bahwa majalah Auleea ketika beriklan tidak mendorong pada pembelian. Pesan yang dominan lebih berupa gambar dan tagline, gambar majalah pada halaman iklan tertulis jelas mengenai judul artikel andalan pada edisi tersebut. Hal ini 
menunjukkan bahwa majalah Auleea ingin menunjukkan kualitas dari majalah auleea secara isi, desain gambar. Selain itu dalam gambar juga sudah tertulis harga dari majalah akan tetapi promosi harga untuk berlangganan tidak disebutkan. Sehingga dalam menyampaikan pesan majalah Auleea tidak menekankan pada harga majalah yang bisa mendorong pembelian. Iklan yang dipasang adalah iklan berwarna dan satu halaman penuh. Hal ini akan lebih menarik minat pelanggan untuk melihat iklan. Selain itu isi pesan lainnya adalah menekankan pada taget pasar majalah ini adalah keluarga muslim modern masa kini. Pesan tentang target pasar ini sekaligus sebagai tagline dari majalah Auleea. Majalah secara tegas dan eksplisit menyebutkan target audiensnya hal ini berarti majalah Auleea dalam menyampaikan pesan secara lebih tegas.

Dalam komunikasi tatap muka dilakukan oleh berbagai pihak. Mulai dari wartawan, wakil pimpinan redaksi dan wakil direktur, koordinator iklan dan pemasaran turut melakukan komunikasi tatap muka. Akan tetapi yang langsung berhadapan dengan pelanggan adalah Ibu Ayunda Rahma dan Ibu Maratus Sholihah. Mereka sudah memahami produk, karena yang memproduksi artikel, mulai dari pemilihan tema, judul dan ilustrasi yang digunakan. Sedangkan bagian distribusi dan agen belum mengetahui karena mereka fokus pada penagihan dan mengantarkan majalah kepada pelanggan. Bagi staf yang ikut bagian produksi, mereka mampu menyampaikan produk dengan baik. untuk kalangan remaja pemasar lebih memperlihatkan daya tarik rasional bisa diperlihatkan permasalahan penampilan yang dialami oleh remaja tersebut. Misalnya dalam hal penampilan seperti permasalahan penggunaan fashion untuk perempuan yang berbadan gemuk, dan lain-lain. Sedangkan untuk ibu-ibu mereka memberikan penjelasan mengenai artikel utama dari majalah yang sedang dipegang oleh pelanggan.

Sedangkan staf yang bukan produksi lebih banyak menggunakan komunikasi yang nonproduk seperti pertanyaan seputar alamat rumah, makanan atau tempat pariwisata yang ada di daerah tersebut tak jarang komunikator memberikan candaan kepada pembeli. Hal ini dilakukan dalam rangka untuk mencerminkan bahwa penjual majalah Auleea adalah orang yang ramah. Akan tetapi ketika dihadapkan dengan pelanggan yang terlihat rapi bersih dan kelihatan berpendidikan maka komunikasi yang dilakukan cenderung to the point mengenai harga majalah.

Terjadi perbedaan pesan yang disampaikan terhadap pelanggan yang berbeda. salah satu komunikator pemasar yang terlibat dalam proses produksi memiliki kecenderungan komunikasi memberikan daya tarik nasional. Sedangkan yang bukan berasal dari staf nonproduksi memiliki kecenderungan penyampaian komunikasi emosional. Setelah ditelusuri komunikator yang nonproduksi tidak membaca dulu isi majalah sebelum dipasarkan. Sehingga pemasar pada event kebingungan apa yang disampaikan kepada pelanggan. Selain itu faktor 
pendidikan dan pengalaman menjadi hambatan utama. Sedangkan faktor kekuatan pada komunikasi pemasar event adalah kepercayaan diri dan keramahan terhadap pelanggan.

Dalam komunikasi event, bentuk simbolisnya adalah ex banner atau fotofoto kover majalah Aula dan Auleea. dengan dipajangnya foto maka pelanggan bisa sekilas melihat bahwa isi majalah juga berkenaan dengan artis-artis modern yang berhijab. Pemasangan kover pada gerai yang dibuat pada event tertentu ini mampu memperlihatkan secara sekilas isi majalah. Poster promosi juga dipasang pada saat event. Hal ini bertujuan agar pembeli melakukan pembelian langsung. Dan mengetahui bahwa terdapat promosi pada saat pembelian hari itu. Sedangkan hari-hari tidak ada. Ex banner juga memperlihatkan secara sekilas mengenai majalah Auleea.

Struktur penyampaian komunikasi pemasaran harus dilakukan secara logis yakni berkaitan dengan penarikan kesimpulan dan urutan presentasi pesan. ${ }^{56}$ Berdasarkan data yang didapatkan bahwa pesan yang disampaikan sebelumnya sudah terstruktur pada saluran komunikasi nonpersonal. sedangkan saluran komunikasi personal lebih sering tidak terstruktur. Pemasar dalam event lebih menekankan keakraban dan tidak fokus pada isi produk atau keunggulan produk. sehingga dalam setiap event pelanggan dipersilahkan untuk melihat sendiri majalah Auleea, dan membukanya perlembar.

\section{Saluran Komunikasi Pemasaran}

Saluran komunikasi terdiri atas saluran komunikasi personal dan saluran komunikasi nonpersonal. Saluran langsung yang dipakai oleh majalah Auleea adalah dengan tatap muka secara langsung dengan komunitas-komunitas yang menjadi target pasar sasar, dan menggunakan ragam media sosial. Sedangkan saluran nonpersonal yang digunakan antara lain: iklan, promo, public relation, dan event.

\section{a. Personal Selling Majalah Auleea}

Majalah Auleea memasarkan pada komunitas-komunitas perempuan muslim. Komunitas yang ditarget terdiri dari kelompok keagamaan seperti kelompok pengajian ibu-ibu atau komunitas pecinta Alquran saja dan komunitas non keagamaan juga dijadikan pasar sasar seperti komunitas orang tua Sekolah Dasar Pucang 2 Sidoarjo, komunitas supermom multi talenta, komunitas pecinta biru, komunitas pecinta film, khadijah sejati yang gemar travelling. Majalah ini sering diundang ke lokasi pengajian dalam menyampaikan seminar kecil-kecilan untuk komunitas. Hal ini dimanfaatkan majalah Auleea untuk melakukan promosi.

Pertemuan tersebut menjadi sarana yang cukup baik untuk meningkatkan penjualan majalah. Dengan kedatangan majalah ini juga ibu-ibu pengajian diminta untuk membeli beberapa eksemplar untuk anggotanya dan mereka akan dimuat dalam rubrik community on frame. Target komunikasi pada personal

56 Ibid., 510. 
selling lebih menekankan pada pembelian berulang. Hal ini dikarenakan dengan majalah Auleea memberikan seminar, maka ada manfaat langsung yang dirasakan oleh pelanggan. Selain pengetahuan yang bertambah mamnfaat yang didapatkan adalah eksistensi pengajian. Karena mereka dimuat dalam rubrik majalah berikutnya. Pesan yang disampaikan dalam seminar adalah pesan yang memiliki keterkaitan dengan majalah seperti parenting dan jurnalistik.

\section{b. Media Sosial Majalah Auleea}

Media sosial yang digunakan untuk promosi adalah instagram @Auleeamagazine, facebook majalah auleea,twitter@majalah_auleea. Media sosial yang digunakan untuk memberikan informasi tentang edisi majalah terbaru, serta kegiatan proses produksi majalah yang meliputi kegiatan fotografi, proses make up dan pemilihan latar tempat serta tidak jarang tentang fashion-fashion yang akan dimuat pada edisi mendatang dan menginformasikan event yang sedang diikuti oleh Majalah Auleea. Sama halnya dengan twitter, majalah Auleea juga menampilkan hal yang sama. Sedangkan untuk media website berdasarkan berdasarkan penuturan narasumber, Ibu Hikmah Bafaqih, saat ini masih dalam tahap perencanaan, karena untuk membuka website butuh sumber daya yang fokus. Auleea ingin memiliki website yang profesional dan jauh dari kesan asalasalan sehingga perencanaanya harus matang. Untuk youtube tidak digunakan oleh majalah Auleea Komunikasi yang dilakukan di media sosial lebih mendalam, hal ini dikarenakan di sosial media terdapat kolom komentar yang bisa membuka peluang komunikasi timbal balik antara pelanggan dengan perusahaan. Bentuk komunikasinya berupa Tanya jawab mengenai produk majalah Auleea. Atau bisa menyampaikan keluhan-keluhan atas pelayanan yang diberikan oleh pihak majalah. Dengan adanya komunikasi timbal balik maka majalah bisa menampung aspirasi dari pelanggan dan bisa menjadikannya bahan masukan agar menjadikan majalah Auleea menjadi majalah yang berkualitas. Sedangkan bagi pelanggan akan menciptakan rasa diapresiasi oleh majalah. Karena mereka lebih didengarkan.

Bentuk komunikasi timbal balik berbentuk survei publik. Orientasi majalah Auleea membuka survei publik di media sosial lebih memudahkan untuk menjaring pendapat dari pembaca, atau pengikut akun majalah Auleea. Sehingga hal ini bisa menjadi pijakan pembuatan bahan artikel. Psikologis pihak yang menjawab survey tentunya juga merasa dilibatkan dalam proses pembuatan. Saluran media sosial bisa diikuti oleh siapa saja, tanpa memandang batasan perempuan atau laki-laki, remaja atau dewasa, dan dari mana saja. Media sosial lebih menjangkau pasar lebih banyak. Saluran komunikasi yang aktif digunakan adalah instagram, hal ini dikarenakan instagram saat ini sedang populer dimasyarakat. Sedangkan media facebook jarang aktif, apalagi media twitter.

Tujuan media sosial bisa beragam. Tetapi yang dilakukan majalah Auleea lebih banyak untuk menggunakan komunikasi ajakan dengan membuat review sekilas 
tentang latar belakang sebuah rubrik diangkat dan jawabannya bisa dibaca pada majalah Auleea edisi berikutnya. Hal ini bisa membuat rasa keingin tahuan pembaca muncul dan bisa mendorong perilaku pembelian.

\section{c. Iklan Majalah Auleea}

Selain iklan di majalah Aula, majalah Auleea juga iklan di radio media fm $100 \%$ tembang Indonesia dan campur sari. Alasan pemilihan media radio dalam rangka untuk menjangkau pasar majalah Auleea lebih luas. Selain itu iklan di media $\mathrm{fm}$ hal ini dikarenakan media ini menyasar pasar kalangan masyarakat yang lebih dewasa. Dari segi pendanaan juga radio secara pembiayaan lebih murah. Selain itu iklan melalui media cetak dikemas lebih colourfull dan iklannya satu halaman penuh. Colourfull dilakukan agar lebih menarik perhatian dari pembaca. Selain itu penggunaan satu halaman penuh bisa lebih terlihat majalahnya. Sehingga saluran iklan ini lebih menekankan pengetahuan dari pada target pembelian.

Iklan di televisi terlalu mahal. Peluang saluran nonpersonal yang bisa dijangkau adalah media televisi lokal seperti TV9 yang berada dibawah naungan PWNU. Akan tetapi selama ini untuk rubrik acara televisi sudah diisi oleh Majalah Aula. Pajangan atau iklan melalui billboard juga tidak dilakukan oleh majalah Auleea, hal ini dikarenakan kendala biaya. Biaya billboard telalu mahal dan tidak menjamin akan dibaca oleh target pasar. Sehingga hal ini tidaklah efektif bagi majalah Auleea.

\section{d. Public Relation Majalah Auleea}

Public relation selama ini yang dilakukan terhadap karyawan adalah dengan memberikan hadiah umroh setiap tahun bagi pegawai yang dianggap telah berjasa dengan perusahaan. Selain itu untuk program humas tidak banyak data yang diketahui oleh penulis. Dalam struktur majalah Auleea juga tidak terdapat struktur fungsi humas. Sehingga dari sini dapat dilihat bahwa majalah Auleea belum memprioritaskan public relation. Untuk mengatasi pihak yang tidak suka terhadap majalah Auleea yang dilakukan adalah menjelaskan dengan baik-baik isi majalah Auleea secara personal. Belum ada program khusus yang dicanangkan untuk mengatasi hal tersebut.

\section{e. Promosi Penjualan Majalah Auleea}

Promosi penjualan dilakukan dengan memberikan beragam bonus pada eventevent tertentu seperti ulang tahun majalah Aula yang ke-40 tahun. Majalah ini juga turut serta memberikan promo untuk pembelian selama 6 bulan akan mendapatkan hadiah Alquran. Selain itu promo pembelian juga diberikan kepada pelanggan yang berlangganan majalah Auleea. Promo berlangganan selama 6 bulan seharga Rp. 140.000,- dan promo berlangganan selama satu tahun seharga Rp. 270.000,-. Selain itu untuk pembelian pertama tidak jarang Majalah Auleea memberikan majalah edisi bulan sebelumnya secara gratis kepada pembaca. Majalah edisi sebelumnya juga dijual dengan harga Rp. 15.000,/eksemplar. Penjualan ini dilakukan untuk menarik pembaca jika harga Rp. 25.000,/eksemplar terlalu mahal. Jika memang dirasa yang datang di stan Auleea tidak 
mampu membeli maka pihak pemasar tidak segan-segan untuk memberikan edisi sebelumnya secara cuma-cuma. Hal ini dilakukan agar mereka bisa mengetahui isi Majalah Auleea. ${ }^{57}$

Selain memberikan insentif berupa bonus, majalah Auleea juga membagikan majalah secara gratis dalam setiap event yang dibuat atau ketika majalah Auleea menjadi media partner. Hal ini bertujuan agar pelanggan bisa mencoba membaca majalah Auleea. sehingga bisa lebih bisa membandingkan antara majalah muslimah yang pernah dibaca. Selain itu bagi pembaca yang belum pernah membaca majalah muslimah bisa menjadi pengetahuan baru mengenai gambaran produk majalah Auleea.

\section{f. Event Majalah Auleea}

Event yang diadakan majalah Auleea selain berorientasi sebagai media pemasaran, juga sebagai bahan reportase untuk rubrik majalah bulan berikutnya. Hal ini sekaligus membuka peluang bagi produk-produk lain untuk iklan di majalah Auleea. Event besar yang diselenggarakan oleh Majalah Auleea adalah pemilihan putri Auleea yang diadakan setiap tahun. Event yang diadakan dengan bekerja sama dengan Fatayat NU ini sejak awal dirancang untuk menunjukkan bahwa perempuan nahdlatul ulama adalah perempuan yang modern yang tidak meninggalkan nilai-nilai ke-Nu-an.

Peserta ajang adalah perempuan remaja yang berusia 16-25 tahun yang belum pernah menikah. Selain itu modis serta memahami nilai-nilai NU, selain itu dalam keseharian para perempuan itu harus berkerudung. Untuk bisa menjadi brand ambassador ada training yang diberikan oleh pihak majalah selama tiga hari untuk mendalami ilmu ke-NU-an serta beragam kebutuhan tentang tugas putri majalah Auleea sebagai brand ambassador dari majalah. Tempat pelaksanaan dipilih ditempat yang ramai serta banyak dikunjungi orang, royal plaza sebagai tempat diselenggaranya ajang ini karena memiliki pasar yang beragam, mulai dari kalangan atas hingga kalangan menengah ke bawah. Setiap orang bisa melihat acara tersebut. Sehingga dengan acara ini bisa semakin mendekatkan diri dengan pasar.

Rangkaian event lain selain pemilihan Putri Auleea adalah hijab class, festival women enterpreneur, bazaar muslim, seminar women socialpreneur, lomba rias pengantin, fashion show, pemilihan Cece \& Keke Muslim Jatim. Panggung putri Auleea ini lebih menekankan pada pernak-pernik fashion wanita dan wanita berkarya. Hal ini ditunjukkan dengan adanya seminar bagi wanita yang juga sedang bergelut dengan sebuah usaha, serta festival women entrepreneur.

57 Hasil Observasi lapangan, saat ikut serta melakukan kegiatan pemasaran di JX Expo Internasional Jl. Ahmad Yani Surabaya. 

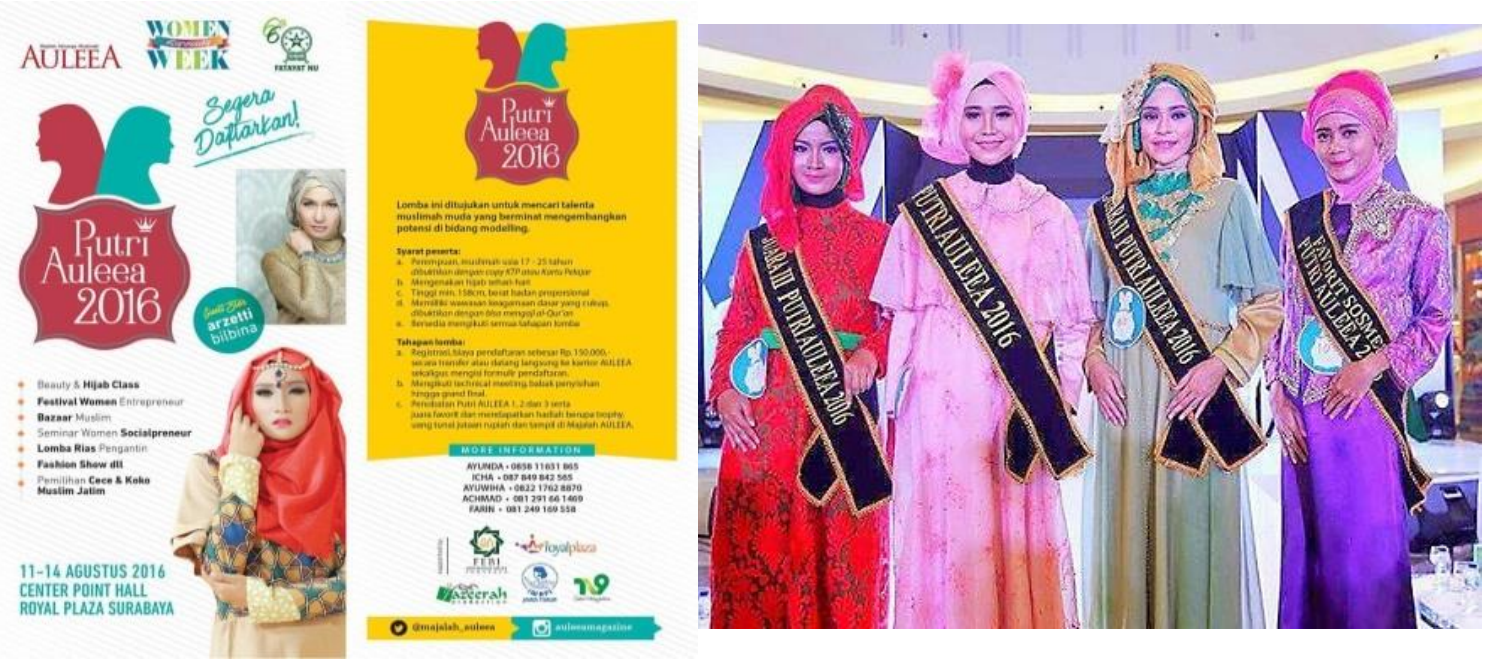

Gambar 2 - Event Putri Auleea di Royal Plaza Surabaya tahun 2016

Majalah Auleea bagi kalangan tertentu merupakan majalah yang mahal, selain itu pasar saing dari majalah ini juga beragam. Pihak yang melakukan pembelian akan mempertimbangkan dengan matang mengenai keputusan pembelian. Oleh karena itu untuk menguatkan pembelian majalah. pemasar memanfaatkan kelompok referen terutama teman untuk melakukan pembelian seperti suami juga bisa mendorong istri untuk berlangganan majalah Auleea. Sehingga ketika majalah Aula melakukan promosi bagi-bagi majalah maka majalah Auleea juga diikut sertakan, agar para suami bisa mengenal Auleea.

Selain event yang dibuat sendiri oleh majalah Auleea, dalam melakukan proses pemasaran majalah Auleea juga menjadi media partner pada event-event yang diselenggarakan oleh perusahaan lain. event yang diikuti tidak boleh sembarangan. Event yang diikuti adalah event tentang pendidikan, tentang pernak pernik penampilan, dan kegiatan keagamaan yang dilaksanakan oleh Nahdlatul Ulama dan lain-lain. Majalah Auleea lebih suka menjadi media partner dibandingkan dengan memberikan sponsor untuk produk tertentu. Dengan menjadi media partner Auleea, diperbolehkan untuk melakukan penjualan di tempat tersebut. gerai yang didirkan menjual dua majalah yakni majalah Aula dan majalah Auleea, di dalam stan terdapat Majalah Auleea dengan beragam edisi mulai dari yang terbaru sampai terbitan tahun-tahun sebelumnya. Selain itu juga bisa melihat tentang video pendek tentang visi misi pembuatan majalah Auleea, $X$ banner tentang majalah Auleea serta kumpulan kover majalah Aula dan Auleea.

Event-event yang pernah diikuti seperti moslem market yang digelar oleh Jawapos di Convention Hall Tunjungan Plaza Surabaya, Moslem Fashion Festival di Royal Plaza, Ciputra World Fashion Week, 
pameran kampus expo di JX Internasional Surabaya, pameran batik di Grand City, Kongres Fatayat NU di Surabaya, Munas NU di Jombang. Setiap event, pemasar juga menyebarkan brosur majalah Auleea kepada pelanggan yang melewati stand, ini dilakukan agar mereka mengetahui Majalah Auleea. Sasaran brosur adalah ibu-ibu, bapak-bapak dan para remaja.

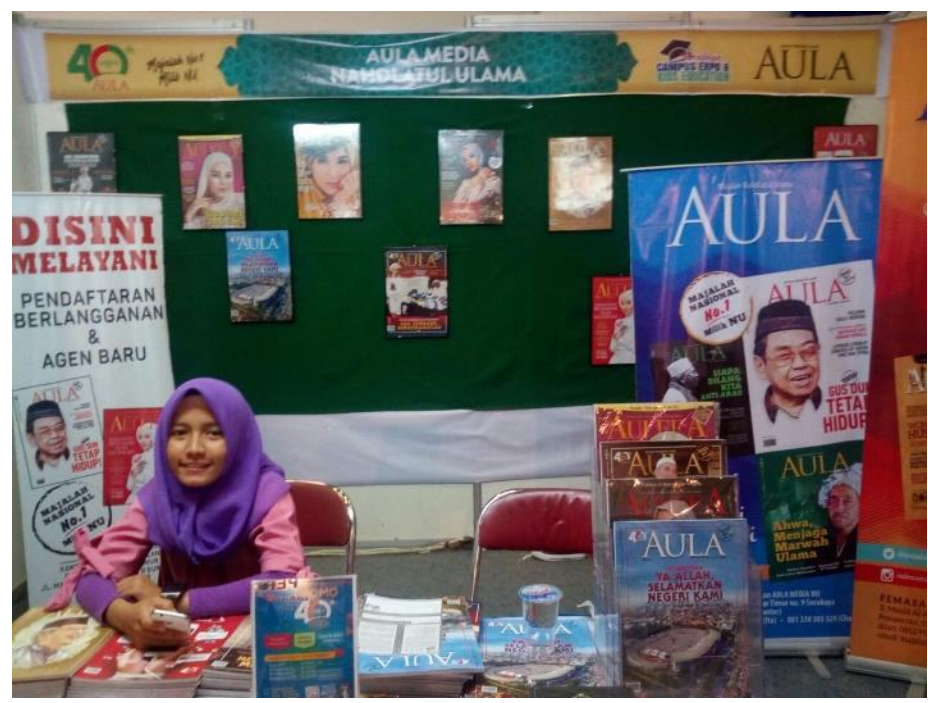

Gambar 3 - Stand Majalah Auleea di Acara Pameran Pendidikan JX Expo Internasional - Surabaya

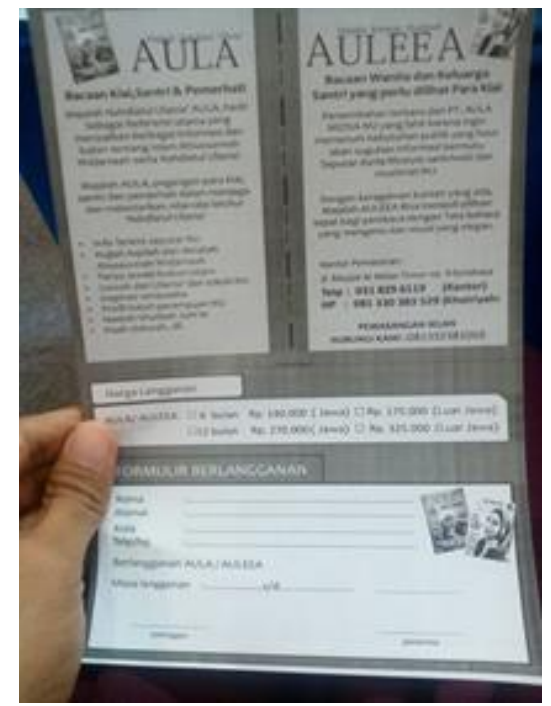

Gambar 4 - Brosur Majalah Aula dan Auleea 
Keikutsertaan Auleea dalam setiap event bisa lebih mendekatkan dengan konsumen, majalah Auleea bisa lebih mendalami pelanggan. Saat ada pembeli yang datang digerai majalah mereka menyambut dengan senyuman dan mempersilahkan pelanggan untuk melihat-lihat majalah. Selain itu mereka juga memberikan sedikit penjelasan mengenai rubrik yang sedang dibaca oleh pelanggan dan sesekali memberikan pertanyaan yang berhubungan dengan topik rubrik pada saat itu kepada pelanggan. Sehingga di sini pelanggan lebih diperhatikan kebutuhannya. Dan memang kebanyakan dari yang datang digerai adalah satu paket keluarga yang terdiri atas ayah, ibu dan anak-anaknya yang ikut mampir di gerai yang telah disediakan. Selain itu juga ada para remaja perempuan juga datang digerai. Tidak sedikit pula yang datang karena melihat simbol Nahdlatul Ulama yang ada digerai. Sehingga membuat pelanggan penasaran terhadap produk dari NU.

Pemasar dalam menyampaikan produknya juga melihat cara berpakaian dari wanita apakah modis atau tidak kalau modis maka kebanyakan akan menunjukkan gaya fashion pada saat ini. Sedangkan kalau ibu-ibu yang memiliki anak remaja, maka bisa ditunjukkan artikel tentang parenting untuk anak usia remaja. Dalam hal ini majalah Auleea dalam melakukan komunikasi sangat memperhatikan karakteristik pelanggan. Pemberian brosur kepada pelanggan lebih menekankan pada pengenalan majalah Auleea. Tidak sampai mengajar pengunjung gerai untuk membeli. Media brosur memiliki kelebihan. Lebih kecil dan 206ias dibaca kembali pada saat memiliki waktu luang. Selain itu dengan media brosur lebih fleksibel dan lebih ringkas untuk menyampaikan informasi.

Tabel 7 - Implementasi Strategi Komunikasi Pemasaran Majalah Auleea

\begin{tabular}{|c|c|c|c|}
\hline & Sasaran & Saluran & Pesan \\
\hline 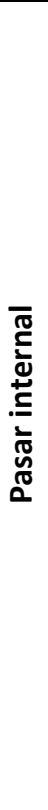 & $\begin{array}{l}\text { Badan otonom } \\
\text { NU Fatayat di } \\
\text { Jawa Timur } \\
\text { Badan otonom } \\
\text { Fatayat NU yang } \\
\text { diluar jawa timur }\end{array}$ & $\begin{array}{l}\text { - Saluran langsung melalui } \\
\text { mendatangi fatayat, } \\
\text { membuat event pemilihan } \\
\text { putri Auleea yang di usung } \\
\text { dari fatayat NU di tingkat } \\
\text { cabang } \\
\text { - Iklan } \\
\text { - Melalu sponsorship sebagai } \\
\text { media partner untuk event } \\
\text { fatayat } \\
\text { - Membuat gerai khusus } \\
\text { majalah Auleea di tempat } \\
\text { dilangsungkannya event dari } \\
\text { pengurus pusat fatayat NU } \\
\text { - Melalui sponsorship sebagai } \\
\text { media partner }\end{array}$ & $\begin{array}{l}\text { Kesamaan nilai-nilai NU, dan } \\
\text { manfaat yang akan didapatkan } \\
\text { setelah berlangganan majalah } \\
\text { terhadap perkembangan NU } \\
\text { Kesamaan nilai-nilai Nahdlatul } \\
\text { Ulama } \\
\text { Isi dari majalah Auleea }\end{array}$ \\
\hline
\end{tabular}




\begin{tabular}{|c|c|c|c|}
\hline & Sasaran & Saluran & Pesan \\
\hline 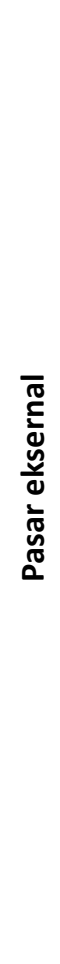 & $\begin{array}{l}\text { Wanita muslim } \\
\text { dari organisasi } \\
\text { masyarakat yang } \\
\text { lain seperti } \\
\text { Muhammadiyah, } \\
\text { LDII } \\
\text { Perempuan } \\
\text { remaja } \\
\text { muslimah yang } \\
\text { meliputi } \\
\text { mahasiswa, } \\
\text { santri pesantren } \\
\\
\text { Komunitas- } \\
\text { komunitas } \\
\text { wanita muslimah } \\
\text { perkotaan }\end{array}$ & $\begin{array}{l}\text { - Iklan } \\
\text { - Membuat event putri auleea } \\
\text { - Pemasaran langsung } \\
\text { - Media sosial } \\
\text { - Pemasaran secara langsung } \\
\text { - Media sosial }\end{array}$ & $\begin{array}{l}\text { - } \text { Produk majalah Auleea dan cara } \\
\text { menjangkau majalah Auleea } \\
\text { - } \text { Menampung kritik dan saran } \\
\text { - } \text { Melalui event maka } \\
\text { mencerminkan } \\
\text { muslimah Auleea } \\
\text { - Produk majalah saat ini dan } \\
\text { ajakan untuk membeli majalah } \\
\text { yang baru } \\
\text { - Pemberian wawasan tertentu } \\
\text { dan ajakan untuk membeli } \\
\text { majalah Auleea untuk } \\
\text { mendapatkan } \\
\text { parenting, fikih, dan lain-lain } \\
\text { yang bisa memenuhi kebutuhan } \\
\text { wanita }\end{array}$ \\
\hline
\end{tabular}

\section{Kesimpulan}

Majalah Auleea dalam mengimplementasikan komunikasi pemasaran memiliki tiga tujuan yakni tujuan kognitif, afektif, dan konasi. Masing-masing tujuan ditetapkan pada pasar yang berbeda satu dengan yang selainnya. Media iklan lebih lebih banyak menekankan pada pengenalan majalah Auleea. Yakni attention dan interest terhadap majalah. Karena untuk bisa mencapai tahap pembelian perlu dilakukan komunikasi yang massive. Sedangkan sumber daya majalah Auleea masih belum mencukupi. Target pembelian lebih ditekankan pada organisasi badan otonom NU karena sudah mengenal Auleea sehingga target komunikasi yang dituju adalah tahap action atau konasi.
Pesan yang disampaikan oleh majalah juga berkaitan dengan dua hal yakni promosi serta lebih menekankan keramahan komunikator pemasaran. Hal ini diwujudkan dengan pesan komunikasi yang lebih banyak eksplorasi pembeli yang meliputi alamat rumah dilanjutkan dengan topik keakraban lainnya. Sehingga kurang menekankan pada nilai penting pembelian produk. Akan tetapi kesan yang didapatkan lebih kepada penjualnya yang ramah. Proses komunikasi pemasaran majalah Auleea lebih menekankan pada media pertemuan secara langsung dibandingkan dengan membuat iklan-iklan yang menyasar banyak orang untuk mengenal Auleea. Hal ini dilakukan agar lebih dekat dengan konsumen dan membuat konsumen melakukan pembelian berulang. 
Program pembangunan loyalitas dilakukan dengan melibatkan komunitas tersebut untuk menjadi kontributor cukup efektif untuk membuat loyal pelanggan karena memunculkan sense of belonging terhadap perusahaan. Selain itu juga program loyalitas dilakukan dengan selalu mengupdate media sosial dan selalu responsif terhadap segala persoalan yang dialami pelanggan.

\section{Bibliografi}

Dianti, Rini. "Strategi Komunikasi Harian Republika untuk Menciptakan Kepuasan Pelanggan: Studi Kasus pada Harian Umum Republika". Jurnal Pemasaran Kompetitif. Vol. I, No. 02/ Januari 2018) 132.

Fandy Tjiptono, Gregorius Chandra, Dadi Adriana. Pemasaran Strategi: Mengupas Topik Utama Pemasaran Strategic, Branding Strategi, Costumer Satisfaction, Strategi Kompetitif, Hingga E Marketing. Yogyakarta: C.V Andi Offset, 2008

Kasali, Rhenald. Membidik Pasar Indonesia: Segmentasi, Targetting, dan Positioning. Jakarta: Gramedia Pustaka Utar, 1998.

Kotler, Philip. Gary Amstrong. Prinsip-prinsip Pemasaran Edisi 12 Jilid 2. Jakarta: Penerbit Erlangga, 2008.

Mahasiswa pasca sarjana UI, "Strategi komunikasi pemasaran majalah Islam Studi kasus pada majalah Islam dengan segmen remaja majalah Annida dan majalah Muslimah" (Tesis-Universitas Indonesia).

Majalah Auleea Edisi bulan November 2015

Majalah Auleea Edisi 28 bulan oktober 2016

Pradita, Yudith. "Strategi komunikasi pemasaran majalah Ummi (PT. Insan Media Pratama) dalam meningkatkan penjualan periode tahun 2012." Skripsi-Universitas Mercubuana, Jakarta, 2013.

Philip Kotler, Kevin Lane Keller. Manajemen Pemasaran Jilid 12 Edisi 2. New Jersey: Pearson Prentice Hall, 2006.

Rachmawati, Amanda Septi. "Strategi Komunikasi Pemasaran dalam Bidang Promosi: Studi Deskriptif Kualitatif Strategi Komunikasi Pemasaran dalam Bidang Promosi terhadap Koran Sindo Jatim di Surabaya". Skripsi, Universitas Pembangunan Negara Jatim, Surabaya, 2013.

Sugiyono. Metode Penelitian Kombinasi (Mixed Methods). Bandung: Penerbit Alfabeta, 2015. Wahyu, Aris. "Strategi Komunikasi Pemasaran Harian Jogja dalam Memasuki Pasar di Jogjakarta”. Skripsi, UIN Sunan Kalijaga, Jogjakarta, 2009. 